\title{
Abstracts from Articles in International Business History Journals
}

\author{
From Entreprises et Histoire [Firms and History] \\ Vol. 51 (Sept. 2008)
}

JoAnne Yates and Craig N. Murphy, "Charles Le Maistre: Entrepreneur de standardisation international" ["Charles Le Maistre: Entrepreneur in International Standardization"]. Standardization has often been viewed as the antithesis of innovation. Yet by constraining it also enables innovation. This paper focuses on Charles Le Maistre, in Joseph Schumpeter's terms a "political entrepreneur," who evangelized for an organizational innovation-voluntary consensus standards setting. During the first half of the twentieth century, he carried this innovation from the U.K. to many other nations as well as into the international realm. During that time, he was central to the formation of a series of international standards organizations, culminating in the global ISO [International Organization for Standardization] that still operates today.

Margaret B.W. Graham, "Henry Phelps Gage, entrepreneur de standardisation à la verrerie Corning (1911-1947)" ["Henry Phelps Gage: Standardizing Entrepreneur at Corning Glass Works, 1911-1947”]. Entrepreneurship and standard-setting activities are usually considered antithetical activities, and for good reason. In this account of Henry Phelps Gage, employee of Corning Glass Works from 1911 to 1947, we have an innovating entrepreneur who was actively involved in setting, negotiating, and maintaining key optical standards, both performance and production, for colored glasses used for signals of all kinds. Gage's role as the company liaison with standards-setting bodies, and his indispensable expertise in measurement, gave him a certain amount of autonomy inside Corning. Gage promoted an entrepreneurial approach to standards, representing performance standards as providing both the strategic opportunities to develop new products for new customers, and the looseness to allow methods and processes to be changed.

Lars Heide, "Le Danish Welding Institute et FORCE Technology, 19402005: Standardisation technique et formation des affaires" ["The Danish Welding Institute and FORCE Technology, 1940-2005: Technical Standardization and the Shaping of Business"]. This paper analyzes how three national and international technical standards regimes shaped the history of the Danish Welding Institute (now FORCE Technology) since the Second World War. It uses the theory of voluntary clubs in 
order to conceptualize the complex interaction of national governments and companies across Europe in writing and applying standards. The theory allows us to understand the differences between the standards regimes. The last regime was established within the framework of the European "Single Market," and the article concludes with a discussion of their role in shaping Europe.

Stève Bernardin and Harrison Grafos, "Rendre la voiture sûre pour le monde? Une perspective transnationale sur les standards de sécurité automobile, 1958-1998" ["Making the Automobile Safe for the World? A Transnational Perspective on Car Safety Standards, 1958-1998"]. Controversies over science in international regulatory bodies are sometimes passed over for economic considerations. Europeans, inspired by functionalist visions guiding postwar rebuilding, advanced a model of majority voting at the United Nations to facilitate economic growth; later the United States would propose its own regulatory model, spurred on by the rise of Japan's auto industry. Two regulatory perspectivesEuropean and American-clash, while China and India emerged as critical to deciding the future of the transnational regulation of the auto industry.

From Zeitschrift für Unternehmensgeschichte [Journal of Business History] Vol. 52, no. 1 (2008)

Karsten Linne, ““. . . bisher nur Sonnentage . . .': Der Aufbau der Volkswagen-Händlerorganisation 1948 bis 1967 ” [““. . . So Far, Only Sunny Days . . ': Setting Up Volkswagen's Dealership Network, 1948-1967”]. Volkswagen's dealership network was exemplary for the automobile industry's overall sales organization. Volkswagen was not able to fall back on an existing dealer network after 1945 and so had to put together a new one. The company opted for a system of independent retailers under a wholesale trade level. The wholesale traders also worked as large retail dealers and triggered a concentration process, becoming very influential and a power factor in their own right vis-à-vis Volkswagen. The development of the dealership network was shaped by changing market conditions, such as new buyer groups, the shift towards a buyer's market, and the behavior of the competition. It was particularly the shift towards a buyer's market that led to the turning away from the hitherto prevalent production orientation to a stronger market, sales, and customer orientation, as well as to a decentralization of the dealer and garage network, while at the same time strengthening sales promotion and advertising. 
Heidrun Homburg, "Financing World Football: A Business History of the Fédération Internationale de Football Association (FIFA)." Using a modern business history approach, this paper analyzes FIFA's strategy and structure since its first "World's Cup" in 1930; it asks how the organization was restructured in the course of its growth; and it intends to show that FIFA's organizational structure changed in accordance with its strategic option for growth and the business success of its main product, the men's football world championship. The first section of the paper illustrates how FIFA's main product and growth evolved over time; the second section analyzes the composition of FIFA's receipts as a means to illuminate FIFA's growth strategies; and the third section follows up the impact of growth on FIFA's organizational structure and asks when and how it was remodeled to better fit FIFA's strategic goals.

Karoline Krenn, "Von der 'Macht der Banken' zur Leitidee des deutschen Produktionsregimes: Bank-Industrie Verflechtung am Beginn des 20. Jahrhunderts" ["From 'Bank Power' to the Leitmotif of the German Production Regime: Bank-Industry Interlocks at the Beginning of the Twentieth Century"]. This article offers a structural analysis of corporate interlocks at the beginning of the twentieth century. The main goal is to point out that bank supervisory boards were increasingly occupied by industrialists, contrary to Hilferding's thesis on "Bankenmacht" (bank power). Supervisory boards became less an expression of dominance ("Herrschaft") of banks over industry than a space for mutual coordination and influence. Among other interlocks are institutions to create and maintain intercorporate cooperation.

Jonas Scherner and Jochen Streb, "Wissenstransfer, Lerneffekte oder Kapazitätsausbau? Die Ursachen des Wachstums der Arbeitsproduktivität in den Werken der Deutschen Sprengchemie GmbH, 1937-1943" ["Knowledge Transfer, Learning-by-doing, or Investment? Explaining Labor Productivity Growth in the Plants of Deutsche Sprengchemie GmbH, 1937-1943"]. During World War II German armament firms increased their labor productivity considerably, and consequently their production of armament goods. Exploring the annual reports that the auditing company Deutsche Revisions- und Treuhand AG drew up for the eight plants of the giant gunpowder producer Deutsche Sprengchemie $\mathrm{GmbH}$, we find, first, that knowledge transfer from old to new plants failed, and, second, that labor productivity growth was primarily caused by localized learning-by-doing effects and investment. As a result, the increase in both productivity and production of Sprengchemie can best be viewed as a continuous microeconomic firm-level phenomenon, rather 
than fostered by pivotal macroeconomic political decisions of armament minister Albert Speer after 1941.

\section{From Revista História Econômica \& História de Empresas \\ [Journal of Economic History and History of Business, Brazil] Vol. 10, no. 1 (2007)}

Cláudia Regina Salgado de Oliveira Hansen and Alexandre Macchione Saes, "Poder Municipal e as Concessões de Serviços Públicos no Brasil Início do Século XX" ["Municipal Power and Public Utilities Concessions in Brazil at the Beginning of the Twentieth Century"]. This paper charts the political and economic path of the Companhia Brasileira de Energia Elétrica (CBEE) in the states of São Paulo and Rio de Janeiro. It identifies the enterprise's obstacles and successes in bidding for municipal concessions. Even though the federal and state decisions were binding for the entire country, there was no national project regarding public utilities concessions. Thus, decisions in Brazil's electric-power sector depended on the economic power and political lobby of entrepreneurs and town councilors.

Gustavo Pereira da Silva and Armando Dalla Costa, "Companhia Ararense de Leiteria (1909-1920): Louiz Nougués e a Realização de um Sonho" ["The Ararense Dairy Company (1909-1920): Louiz Nougués and the Realization of a Dream"]. The dairy industry's challenges included how to preserve milk and how to make a number of products from it. Many companies and entrepreneurs entered this field to research and create new products and to combine new factors of production. The objective of this article is to describe the trajectory of the Ararense Dairy Company (1909-20), situated in Araras. We present the thesis of João Manuel Cardoso de Mello as the best explication of this firm. The article rescues the literature that deals with the controversy of Brazilian industrialization from the end of the empire.

Julio Cesar Bellingieri, “Origem e Evolução da Aglomeração de Empresas Fabricantes de Filtros de Água em Jaboticabal-SP, 1920-2005” ["The Origin and Evolution of the Conglomeration of Water Filter Manufacturers in Jaboticabal, 1920-2005"]. This article studies the advent and evolution of the conglomeration of water-filter manufactures in Jaboticabal municipality, the biggest filter-manufacturer center in Brazil (twenty-four companies with 70 percent of national production). The study identifies three conglomeration phases: the first (1920-52), which saw the foundation of four main companies; the second (1952-90), in which the conglomeration consolidated, other companies were founded, 
and some of the pioneers reached the national market; and the third phase, begun in 1990, which saw the beginning of the conglomeration's decay, when some companies closed down due to the decrease of filter usage in people's homes. The article also analyzes the importance of Jaboticabal's companies for the Brazilian water-filter industry today.

\section{From Investigaciones de Historia Económica \\ [Research in Economic History, Spain]}

Vol. 8 (Spring 2007): Norma Lanciotti, "Empresas autónomas y grupos de inversión: Las empresas del grupo Morrison en Rosario, Argentina (1890-1930)" ["Free-Standing Companies and Investment Groups: The Morrison Companies in Rosario, Argentina (1890-1930)"]. In order to examine the historiographical debate about the decreasing profitability of British investments in Argentina from the first postwar period onward, the performance of two English public-utility companies in Rosario-Rosario Waterworks Company and Rosario City Improvements -are analyzed. Despite the fact that the two companies were under the control of the same investment group (Morrison), their performances diverged. Through analysis of accounting data, the article examines the firms' management and the elements that influenced their revenues and profitability: waterworks and sewerage-utilities production conditions and demand, their relationship with authorities according to the concession terms, and their managerial strategies in changing domestic and international capital markets.

Vol. 8 (Autumn 2007): María Inés Moraes Vázquez, "Crecimiento del Litoral rioplatense colonial y decadencia de la economía misionera: un análisis desde la ganadería" ["River Plate Growth and Paraguayan Missions Decline in the Late Colonial Period: Contrasting Trajectories of Cattle-Raising Economies"]. This paper discusses economic and demographic differences among Rio de la Plata regions during the seventeenth and eighteenth centuries. The focus is on the establishment of cattle-raising around Jesuit missions, their economic and social features, and their rise and decline. A comparison between the performance of the Litoral region's output as a whole and the missions' output during the eighteenth century is presented. Some central issues on markets and institutions concerning herd production in the region are analyzed.

Vol. 10 (Winter 2008): Mario Cerutti, "Crisis y reconversión del tejido productivo en un espacio regional del norte de México: La Laguna (1875-1975)" ["Crisis and Productive Reorganization in a Regional 
Economy of Northern Mexico: La Laguna (1875-1975)"]. The aim of this study is to describe the basic trends of a productive reorganization process that took place in northern Mexico in the middle of the twentieth century. Supported by specialized agriculture and by agro-industry since the end of the nineteenth century, the cotton region known as La Laguna faced a severe transformation process, which included: a) new productive methods; b) the reorientation of business activities; c) the introduction of important technological innovations; d) the search for new markets; e) alternative ways of association among producers; and f) a solid institutional presence. Based on these factors, the most important area of dairy production in the country was created in a semiarid region. This process finally led to the formation of the most powerful food industry in modern Mexico: the LALA group.

Vol. 11 (Spring 2008): Andrés M. Regalsky and Elena Salerno, "En los comienzos de la empresa pública argentina: La Administración de los Ferrocarriles del Estado y las Obras Sanitarias de la Nación antes de 1930" ["The Beginning of Public Enterprise in Argentina: Administración de los Ferrocarriles del Estado and Obras Sanitarias de la Nación before 1930"]. In this work we examine the emergence and development of two of the first Argentine public enterprises organized during the twentieth century: Administración General de los Ferrocarriles del Estado (State Railways National Administration) and Obras Sanitarias de la Nación (Water and Drainage National Works), created in 1909 and 1912, respectively. The trajectory of both entities is examined and compared, as well as their origins during the last third of the nineteenth century and the process through which they managed to achieve a certain autonomous character. In this sense the investment process-connected with the great increase in expenditure and public investment by the state-is examined in relation to the rentability achieved and the formation, in both entities, of a staff of public servants.

Vol. 12 (Summer 2008): Andrea Lluch, “Las agencias de informes crediticios en la Argentina: Una aproximación al funcionamiento de los mecanismos informativos en el mercado crediticio (1892-c. 1935)" ["Credit-Reporting Agencies in Argentina: A Historical Exploration of Information-Sharing Mechanisms in Credit Markets, 1892-c.1935”]. During the last decades, economic theory has devoted considerable attention to the role of information asymmetry in credit markets and problems connected with this phenomenon. However, institutional aspects -particularly, how information is gathered and shared-have not been studied as thoroughly. Only recently has research been conducted on the origins of credit-reporting agencies and on the different responses 
lenders designed to minimize the impact of information asymmetries. As far as Latin America is concerned, there is no previous historical research available. In that sense, this paper aims to depict some of the mechanisms used within the Argentine business community at the beginning of the twentieth century to generate and disclose information about borrowers, with particular emphasis on Argentina's first creditreporting agencies. 